\title{
AN ASSESSMENT OF NATIONAL HOUSING NEEDS
}

\author{
Nathaniel S. Keith*
}

\section{INTRODUCTION}

It is clear that total housing needs in the United States, in terms of existing and projected future requirements, are a product of four principal factors:

First, the needs of the current population and the future needs for housing based on the official projections of population growth and net household formation.

Second, the condition of the existing housing supply.

Third, the financial ability of the various segments of the U.S. population to pay for shelter.

Fourth, the accepted goals and standards of the nation for the housing of the population as a whole.

To reverse the sequence of these four factors, since 1949 it has been the official policy of the United States to achieve eventually a "decent home and a suitable living environment for every American family." This policy was established by the preamble of the Housing Act of $x 949^{1}$ and has remained the official national goal through succeeding Congresses and presidential administrations. The main purpose of this article is to appraise the progress-or limitations-in meeting this goal during the eighteen years since its establishment, to assess the related implications springing from the rapid population growth, to examine the performance of the housing industry and of special federal programs in advancing toward the goal, and to consider particular problems affecting that progress and various proposals to meet them.

\section{National Housing NeEds}

The general dimensions of the prospects for massive population growth in the United States are presumably well recognized. However, it seems doubtful that the full import of this growth in terms of future housing needs has as yet penetrated the national consciousness.

With total population soon to reach the 200 million mark, the median official projection is that there will be further growth to about 260 million by 1985 . This

*A.B. 1929, Brown University. Urban Renewal and Housing Consultant. President, National Housing Conference, Inc.; Trustee, Foundation for Cooperative Housing; Member, Advisory Committee on Housing and Urban Development, Agency for International Development, U.S. Department of State. Author, University Hrll, Syrscuse, N.Y. (1967); The Future of Downtown Rochester, N.Y. (1965); co-author [with Carl Feiss], The Community Renewal Program for the U.S. Virgin Islands (I966); The Community Renewal Program for Rochester, N.Y. (1963); The Future of Buffalo, N.Y. (1958); The Renewal Possibilities of the Historic Triangle of San Juan, Puerto Rico (1955); [with James Rouse], No Siums in Ten Years, Washington, D.C. (I955).

${ }_{42}$ U.S.C. $\$ 144 \mathrm{I}(1964)$. 
TABLE $\mathbf{r}$

Condition of Occupied Housing Units, Inside and Outside Standard Metropolitan Statistical Areas, ig6o

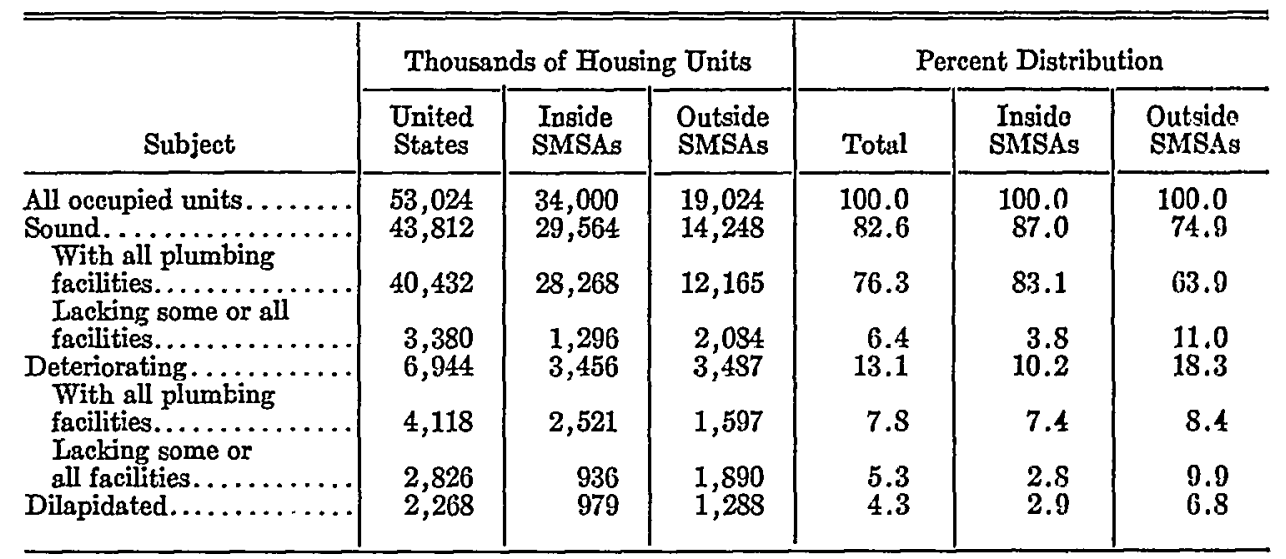

Source: U.S. Bureau of the Census, Department of Commerce.

will represent an increase of about one-third in two decades, representing $\sigma_{5}$ million people and about 20 million households.

In relation to the national goal of achieving a satisfactory standard of housing for the entire population, the implications of this sharp population growth on future housing needs are compounded by the unsatisfactory condition of much of the existing housing supply. As shown in table $\mathrm{I}$, the rg60 Census of Housing reported that close to I2.6 million occupied housing units, or twenty-four per cent of all occupied units, were deteriorating, dilapidated, or lacking some or all plumbing facilities. Within the standard metropolitan areas, the percentage of deficient units was seventeen, or a ratio of about one in six; outside metropolitan areas, the percentage was thirty-six per cent, or a ratio of more than one in three, reflecting in part the high incidence of deficiencies in farm and rural non-farm housing.

In addition, from observation it is clear that many of the so-called standard dwellings are obsolete or obsolescent, poorly located, or deficient in modern facilities, and will require replacement before the end of this century.

There may have been some improvement in this situation during the past seven years, although comprehensive national statistics will not be available until the 1970 Census is tabulated. However, as will be discussed later in this paper, on the basis of the slow rate of progress in corrective programs, it is doubtful that there has been any marked decrease since 1960 in the percentage of deficient housing in the nation as a whole.

The correlation between occupancy of substandard housing and substandard incomes is obvious. However, the implications of this correlation from the standpoint of housing needs are emphasized by the significant statistics on poor households 
TABLE 2

Number of Poor Households and Incidence of Poverty, I959, I962, ANd 1965

\begin{tabular}{|c|c|c|c|c|c|c|}
\hline & \multicolumn{3}{|c|}{$\begin{array}{c}\text { Number of Poor Households } \\
\text { (Millions) }\end{array}$} & \multicolumn{3}{|c|}{$\begin{array}{l}\text { Incidence of Poverty (percent of } \\
\text { total households in the category) }\end{array}$} \\
\hline \multirow{3}{*}{ 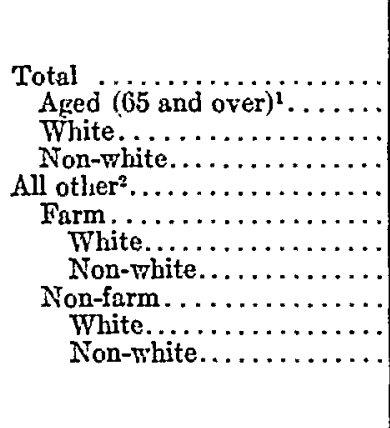 } & 1959 & 1962 & 1965 & 1959 & 1962 & 1965 \\
\hline & $\begin{array}{r}13.4 \\
3.9 \\
3.5 \\
.4 \\
9.4 \\
1.5 \\
1.1 \\
.4 \\
8.0 \\
5.7 \\
2.2\end{array}$ & $\begin{array}{r}12.6 \\
3.8 \\
3.3 \\
.4 \\
8.9 \\
.9 \\
.7 \\
.2 \\
7.9 \\
5.5 \\
2.4\end{array}$ & $\begin{array}{r}11.5 \\
3.8 \\
3.4 \\
.5 \\
7.6 \\
.7 \\
.5 \\
.2 \\
7.0 \\
4.9 \\
2.0\end{array}$ & $\begin{array}{l}24 \\
49 \\
47 \\
73 \\
20 \\
40 \\
34 \\
86 \\
18 \\
15 \\
47\end{array}$ & $\begin{array}{l}22 \\
41 \\
39 \\
64 \\
18 \\
31 \\
25 \\
81 \\
17 \\
14 \\
47\end{array}$ & $\begin{array}{l}19 \\
39 \\
37 \\
65 \\
15 \\
24 \\
18 \\
76 \\
15 \\
12 \\
37\end{array}$ \\
\hline & \multicolumn{3}{|c|}{ Billions of Dollars } & \multicolumn{3}{|c|}{ Percent of GNP } \\
\hline 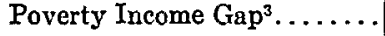 & 13.7 & 12.8 & 11.0 & 2.8 & 2.3 & 1.6 \\
\hline
\end{tabular}

${ }^{1}$ One- and two-person hot soholds with head aged 65 and over.

2 All houstholds headed by a person under 65 and families of three or more headed by an aged person.

3The poverty income gap is the amount which would raise money income of all poor households over the poverty threshold.

Source: U.S. Department of Commerce; U.S. Department of Health, Education \& Welfare.

and incidence of poverty set forth in table 2. In this table, a household is statistically classified as poor if its total money income falls below levels specified by the Social Security Administration, currently $\$ 1,570$ for an unrelated individual, $\$ 2,030$ for a couple, and $\$ 3,200$ for a family of four. (Median family income is estimated at $\$ 6,569$ as of March I965.)

While considerable improvement has been shown since I959, the fact that II.5 million households, or almost one out of five, were in the poverty area in 1965 gives further weight to the crucial nature of housing needs among the poor. Aside from the six per cent of poor families living in low rent public housing, the realistic assumption is that the great predominance of poor households is occupying substandard housing.

To meet the combined objectives of accommodating the housing needs generated by population growth and eventually replacing present substandard dwellings, there is a growing consensus that gross annual housing production in the general range of 2.5 million units per year will be essential. The Board of Directors of the National Housing Conference, Inc., representing a clearing house of public interest organizations, professional groups, and organized labor on housing and community development matters, recently expressed this consensus as follows: ${ }^{2}$

Here is a suggested schedule of programs needed to accomplish our objectives now and for the coming decades:

\footnotetext{
${ }^{2}$ National Housing Conference Legislative Proposals, approved April 9, x967. (These proposals have been' reprinted in II3 CoNG. Rec. H4799 (daily ed. April 27, 1967).)
} 
I. Massive programs to increase and improve the national housing supply through measures which will raise production to the absolute minimum of 2.5 million dwelling units per year, eliminate slums, blight and deterioration within 20 years, and provide for other needed replacements and for housing mobility.

....

To achieve the housing priority proposed above, it will be necessary to build a total of 45 to 57 million new dwelling units in the next 20 years; the high range in this projection would represent in effect the equivalent of the entire national housing stock in existence in 1960 . This would represent an average 20-year annual production rate of between 2.2 million and 2.8 million units a year, with a rate in excess of these averages during the closing years of these decades in order to offset the lead-time which would be involved in expanding production up to the required levels. These projections contemplate accommodating the anticipated net household formation over the next 20 years, the replacement of existing substandard housing as well as of the units which will be eliminated by other demolition or losses, and the replacement of other presently existing housing at an annual rate of one percent to two percent of the present national inventory.

As shown in table 3, actual total housing production has consistently fallen far below this target. In fact, in Ig66 total housing starts declined to the lowest annual level since 1946 , reflecting in large part the shortage of private mortgage funds and the rise in conventional mortgage interest rates to 6.44 per cent in December 1966 , from 5.78 per cent in December 1965 , an increase of about one-ninth. ${ }^{3}$

TABLE 3

New Housing Units Started (Private and Public)

\begin{tabular}{|c|c|c|c|}
\hline & $\begin{array}{c}\text { Total } \\
\text { Farm and } \\
\text { Non-Farm }\end{array}$ & $\begin{array}{c}\text { Non-Farm } \\
\text { Private } \\
\text { Single-Family }\end{array}$ & $\begin{array}{c}\text { Non-Farm } \\
\text { Private } \\
\text { 2-Units or Moro }\end{array}$ \\
\hline 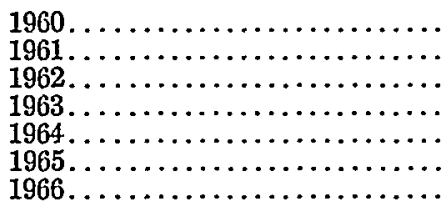 & $\begin{array}{l}1,296,000 \\
1,365,000 \\
1,492,000 \\
1,640,900 \\
1,590,700 \\
1,542,700 \\
1,252,300\end{array}$ & $\begin{array}{l}973,000 \\
946,000 \\
968,000 \\
993,200 \\
944,500 \\
940,000 \\
771,000\end{array}$ & $\begin{array}{l}257,000 \\
339,000 \\
471,000 \\
588,500 \\
585,900 \\
542,700 \\
426,000\end{array}$ \\
\hline
\end{tabular}

Source: U.S. Bureau of Census, Department of Commerce.

This disparity between actual housing production and recognized total needs reflects primarily the fact that new housing construction costs plus related costs for improved land can be absorbed at market financing rates only by the upper half of the income ranges of the national population. Thus, the lower income range of the population, where housing needs are the most acute, is generally outside the market which can be served by the private housing industry in so far as new dwellings are concerned.

\footnotetext{
${ }^{3}$ This data was obtained from the Federal Home Loan Bank Board.
} 
Currently, this disparity is further accentuated by the shortage of private mortgage funds and the inflation in mortgage interest rates. Over the long term, it also reflects the rise in construction costs which historically have risen at a faster rate than the consumer price index as a whole. Between 1959 and 1966 , while the Bureau of Labor Statistics consumer price index was rising from IOI.5 to Ir2.9, an increase of Ir.4 points, the Boesch residential construction cost index was increasing from 102.5 to I20.I, an increase of I7.6 points.

As shown by table 4 , the average estimated construction cost of privately-owned dwelling units increased by fourteen per cent between I963 and I966. While part of this rise may reflect an increase in the average size and equipment of private housing, examination of the construction cost index indicates that rising costs are the principal factor. The statistics in table 4 represent construction cost only. The estimated median sales price of a single-family home in December Ig66 was $\$ 20,700$, including land, according to the Bureau of the Census.

TABLE $_{4}$

Average Construction Cost of Private and Public Non-Farm Housing Starts, I963-Ig66

\begin{tabular}{|c|c|c|c|}
\hline \multirow[b]{3}{*}{ 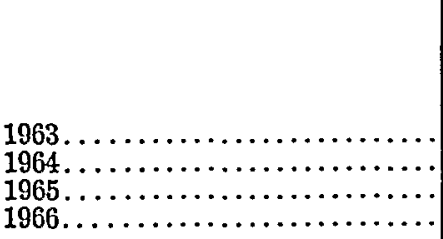 } & \multicolumn{2}{|c|}{ Privately-owned } & \multirow[b]{2}{*}{ Publicly-owned } \\
\hline & 1-family & Total & \\
\hline & $\begin{array}{r}\$ 14,825 \\
15,600 \\
16,250 \\
17,000\end{array}$ & $\begin{array}{r}\$ 12,625 \\
13,125 \\
13,650 \\
14,375\end{array}$ & $\begin{array}{r}\$ 11,925 \\
12,450 \\
12,625 \\
12,625\end{array}$ \\
\hline
\end{tabular}

Source: U.S. Bureau of Census, Department of Commerce.

\section{II}

\section{Meeting the Unserved Housing Needs}

There has been growing recognition over the years of the necessity for supplemental financing programs to meet the needs of families and individuals with incomes below the level at which new standard private housing could be afforded.

The initial major step in this direction was, of course, the enactment of the Housing Act of $1937^{4}$ which established the federally-aided, low rent public housing program. After a lapse during the Second World War period and the immediate postwar years, the program was reactivated and expanded by the Housing Act of I949. Again, additional annual federal subsidy was authorized by the Housing Act of $196 \mathrm{I}^{6}$ and by the Housing and Urban Development Act of $1965 .{ }^{7}$ The latter statute contemplated annual production of 35,000 new public housing units per year and

\footnotetext{
' United States Housing Act of 1937, ch. 896, 50 Stat. 888.

${ }^{6}$ Ch. 338,63 Stat. 413 (codified in scattered sections of 12,42 U.S.C.).

- Pub. L. No. $87-70, \S 303,75$ Stat. 166.

${ }_{42}^{7}$ U.S.C. $\$_{1453}$ (b) (Supp. II, $1965-66$ ).
} 
the provision of approximately 25,000 units per year through rehabilitation or through the leasing of existing private housing suitable for this purpose. Through administrative action, efforts are also currently being made to further broaden the base for the production of public housing through the so-called "turnkey" approach under which private developers may submit proposals to local housing authorities for construction of public housing units based on their own sites and their own plans for sale to the local authorities upon completion. The objective is to increase the flexibility of the program by introducing private initiative and to substantially shorten the long lead-time required for the development of new public housing through the conventional channels.

The Housing Act of $196 \mathrm{x}$ also initiated a program for the private development of housing for low or middle income families at a subsidized interest rate. ${ }^{8}$ Under this program, FHA insurance commitments are issued to nonprofit, cooperative, or limited distribution sponsors for the development of new or substantially rehabilitated housing for occupancy by families or individuals in moderate income brackets, which are administratively defined as below the median income in the particular locality. The mortgage interest rate is limited to three per cent, the FHA mortgage insurance premium is waived, and the permanent mortgage is purchased by the Federal National Mortgage Association.

Another major innovation in federal housing programs to meet the special housing needs of low income families and individuals was the rent supplement program enacted by the Housing and Urban Development Act of $1965^{\circ}$ Under this program, the FHA insures mortgages at market interest rates (currently six per cent) to private nonprofit, limited distribution, or cooperative mortgagors for new or substantially rehabilitated housing. In order to accommodate low income families and individuals in such housing, the Secretary of the Department of Housing and Urban Development is authorized to enter into contracts with such mortgagors to provide annual rent supplements covering the difference between the full rents required to support the project and twenty-five per cent of the total family income of low income occupants, who are required by statute to have incomes at admission within the eligibility ceilings for admission to federally-aided low rent public housing in the particular locality.

These three programs are also intended to give special relief to the housing needs of low and moderate income elderly couples and individuals. In addition, section 202 of the Housing Act of $1959^{10}$ established a program of direct low interest federal loans (currently limited to three per cent) from the Department of Housing and Urban Development to finance housing by nonprofit sponsors for elderly couples and individuals. As was shown in table 2, the incidence of low incomes among the

\footnotetext{
${ }^{8}$ I2 U.S.C. $\$$ I7I5l(d) (3) (Supp. II, 1965-66).

' 12 U.S.C. \$ r7oIs (Supp. II, I965-66).

${ }^{10}$ I2 U.S.C. I70Iq (I964, Supp. II, I965-66).
} 
elderly is especially pronounced. There also exists a special FHA market rate insurance program for housing for the elderly. ${ }^{11}$

While these programs represent important steps in meeting unserved housing needs, the volume of accomplishment has been marginal in relation to the overall dimensions of the needs. This has reflected in part the political controversy still generated by the use of direct federal subsidy for housing. In the case of the federallyaided low rent public housing program, the limitations have been compounded by local difficulties in securing agreement on acceptable sites, which have frequently involved racial overtones, and by the tax exempt status of public housing projects. In the case of the special FHA programs, the limitations appear to reflect the absence of any strong financial incentive to the overall private housing industry to undertake such projects on a broad scale and the difficulties encountered in developing effective nonprofit organizations as an alternative source for volume production.

In the thirty-year history of the federally-aided, low rent public housing program, total production has amounted to only 636,000 completed dwelling units, representing little more than one per cent of the total existing housing supply in the nation. While the broadened and more flexible approaches toward providing public housing as previously described may hopefully expand future accomplishment, the production record through ig66, as shown in table 5, does not reflect such a trend.

\section{TABLE 5}

Publicly-owned Housing Starts (Units)

\begin{tabular}{|c|c|c|c|}
\hline & Federally-assisted & Other & Total \\
\hline 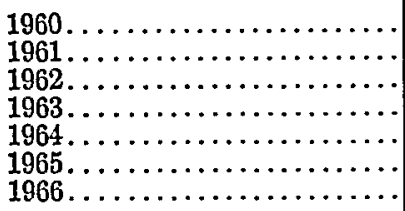 & $\begin{array}{l}26,500 \\
28,200 \\
19,800 \\
24,000 \\
22,700 \\
30,100 \\
28,700\end{array}$ & $\begin{array}{r}17,400 \\
23,800 \\
9,900 \\
7,800 \\
9,400 \\
6,800 \\
2,500\end{array}$ & $\begin{array}{l}43,900 \\
52,000 \\
29,700 \\
31,800 \\
32,100 \\
36,900 \\
31,200\end{array}$ \\
\hline
\end{tabular}

Source: U.S. Bureau of Census, Department of Commerce.

In the case of the FHA below market interest rate program for moderate income families and individuals under section $22 \mathrm{r}(\mathrm{d})(3)$, the total insurance written from the establishment of the program in 196r through the end of I 966 involved only 52,000 dwelling units, of which 13,000 were insured during 1966 . Likewise, as shown by table 6 , the rate of production under the special program for housing for moderate and low income elderly families and individuals has been of very modest proportions (it is significant, however, that about two-thirds of the federally-aided low rent public housing units started in 1966 were for the elderly, indicating substantially greater local political acceptance for this phase of the public housing program).

${ }^{11}{ }_{12}$ U.S.C. 5 1715V (1964, Supp. II, 1965-66). 
TABLE 6

Federally-Assisted Housing Construction for Senior Citizens by Dwelling Units, $1963-1966$

\begin{tabular}{|c|c|c|c|}
\hline & $\begin{array}{c}\text { Direct Loans } \\
\text { (Net Loans Executed) }\end{array}$ & $\begin{array}{c}\text { Low-Rent } \\
\text { Public Housing } \\
\text { (Units Strarted) }\end{array}$ & $\begin{array}{l}\text { FHA Insured } \\
\text { (Units Started) }\end{array}$ \\
\hline 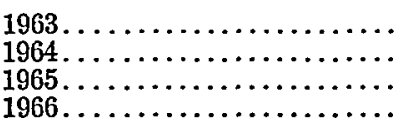 & $\begin{array}{l}4,350 \\
4,753 \\
4,641 \\
5,707\end{array}$ & $\begin{array}{r}8,810 \\
12,401 \\
17,420 \\
19,780\end{array}$ & $\begin{array}{l}8,207 \\
\mathbf{5}, 005 \\
5,237 \\
1,340\end{array}$ \\
\hline
\end{tabular}

Soutce: Hodemio Assigtakce Adyintstration asd FederaI Hodsing Adyinistratios.

Actual development of housing under the rent supplement program has been slow because of delays in funding the program in Congress. The initial appropriation of $\$ 12$ million (representing contract authority for annual rent supplement payments) was not voted until May 1966 and the second appropriation of \$20 million occurred in the fall of rg66. The combined appropriation was less than half the $\$ 65$ million authorized by the 1965 act and is sufficient to cover about 53,000 dwelling units at an assumed average rent supplement of $\$ 600$ per year per unit or $\$ 5^{\circ}$ per month. Under the 1965 act, additional appropriations are authorized in the amount of $\$ 40$ million in the fiscal year beginning July $x, 1967$ and $\$ 45$ million in the fiscal year beginning July $I$, rg68. If fully funded (which appears doubtful on the basis of past congressional action), these would be sufficient to cover an additional I42,000 units.

As of August II, I967, funds had been earmarked in the amount of $\$ 32,000,000$ by the Department of Housing and Urban Development for 43 I rent supplement projects in 284 cities involving $33,96 \mathrm{I}$ rent-supplemented dwelling units.

Later in this article there will be a presentation of current recommendations for measures to substantially enlarge the production of housing in the areas of the most critical needs among moderate and low income families and individuals. However, the dimensions of these needs as previously cited together with the large volume of deficient housing now in use, predominantly by the low income segment of the population, emphasizes the potential importance of large scale rehabilitation of existing housing at least as an interim supply of decent shelter.

Such large scale rehabilitation has in principle been a major objective of the federally-aided urban renewal program since I954 when the Housing Act of 1954 was enacted. Here again, however, the overall accomplishments in relation to the total volume of deficient housing have been small. On the basis of statistics from the Renewal Projects Administration of the Department of Housing and Urban Development, the status of rehabilitation in urban renewal projects as of June 30,1966 is shown in table 7 .

Evidence of increasing local interest and activity in rehabilitation as part of urban renewal is indicated by the fact that as of December 31, 1966, 231 (forty-eight per 


\section{TABLE 7}

Status of Residential Rehabilitation in Federally-Aided Urban Renewal Projects, JUNE 30, 1966

\begin{tabular}{|c|c|}
\hline 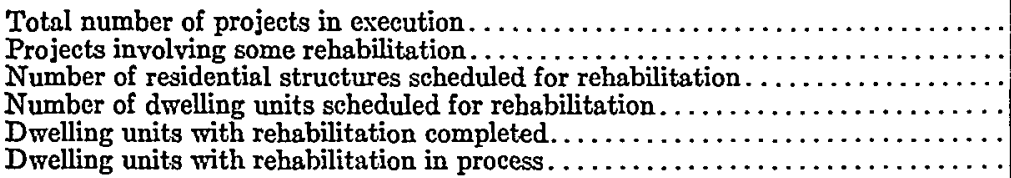 & $\begin{array}{r}1,119 \\
307 \\
72,387 \\
185,267 \\
60,319 \\
26,336\end{array}$ \\
\hline
\end{tabular}

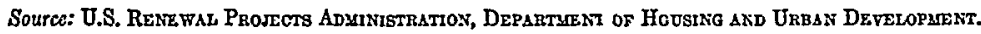

cent) of the 485 urban renewal projects in the planning stage will involve rehabilitation of existing housing in various proportions.

In efforts to stimulate greater activity in rehabilitation of existing housing, special provisions have been enacted by Congress to facilitate the financing of such rehabilitation. These have included special FHA insurance for residential rehabilitation in urban renewal areas under section $220(\mathrm{~h})$ of the National Housing Act of I934, as amended; ${ }^{12}$ direct federal loans at three per cent interest rate up to \$ro,000 per dwelling unit for rehabilitation in code enforcement areas; ${ }^{\mathbf{1 3}}$ and direct grants of up to $\$ 1500$ to enable low income homeowners in urban renewal areas and code enforcement areas to bring their homes up to required standards. ${ }^{14}$ The latter two provisions were incorporated in the Housing and Urban Development Act of 1965. Here again, actual performance has been of small proportions.

The special FHA section 220 (h) program has been virtually inoperative, presumably because of lack of interest on the part of private lenders in making such loans. Under the three per cent direct rehabilitation loan program, as of December I966, 649 loans involving 916 dwelling units in the amount of $\$ 3,200,000$ had been issued. On that same date, I,gIg rehabilitation grants to low income owneroccupants in the amount of $\$ 2,784,000$ had been approved.

It is therefore apparent that most of the rehabilitation which has been actually carried out in urban renewal areas has been conventionally financed rather than undertaken under the special federal program.

Still another approach to broadening the use of the existing housing supply and improving its quality is a program for two-thirds federal grants to localities for carrying out concentrated code enforcement programs in areas where the existing housing can be brought up to local code standards at reasonable costs. ${ }^{15}$ This program was established by the Housing and Urban Development Act of 1965 and is still in its early stages. However, as of June $\mathrm{I} 966$, code enforcement grants, which can also cover

\footnotetext{
${ }^{12}$ 12 U.S.C. $\$$ I715k(h) (1964, Supp. II, 1965-66).

${ }^{13} 42$ U.S.C. $\$ 1452 b$ ( 1964 , Supp. II, I965-66).

${ }^{14} 42$ U.S.C. $\$ 1466$ (Supp. II, 1965-66).

${ }_{18} 42$ U.S.C. $\$ 1468$ (Supp. II, I965-66).
} 
up to two-thirds of the costs of improving public facilities in an area, had been approved for twelve projects containing 38,382 dwelling units of which 20,134 involved one or more local code violations.

\section{Conclusion and Recommendations}

From the previous discussion in this paper of the nature and dimensions of the national housing needs not now being adequately served by the private housing or by existing federal-aid programs, it is clear that massive expansion in those programs and no doubt the establishment of additional and broader approaches will be necessary if the ultimate goal of satisfactory housing for the entire population is to be substantially achieved in the foreseeable future.

Over the near term, the fiscal demands of the Vietnam war constitute a barrier against expansion of existing programs or the enactment of new ones.

In the previously cited report of the Board of Directors of the National Housing Conference on March 17, I 967 , these questions were examined. The conclusions and recommendations of this professional group with respect to matters discussed in this article may be summarized as follows:

I. The administration of existing programs for low and moderate income housing and rehabilitation should be made more forceful, more expeditious, and more sympathetic to the objectives of these programs.

2. Program funds for moderate income housing temporarily impounded by the Administration because of fiscal stringencies should be released. Some relief in this direction has already occurred with the lessening of inflationary pressures.

3. The Congress should fully fund the rent supplement and model cities programs which it authorized in $\mathrm{r}_{965}$ and $\mathrm{rg} 66$.

4. A national goal should be established to expand production of housing for low and moderate income families and individuals to an annual average of 500,000 dwellings to produce a total of ro million dwellings for this critical segment of national housing needs by 1987 . This should include expanding the public housing program to a rate increasing the supply by 125,000 units a year, including full use of the new approaches previously described. It should include an expansion in the mortgage backing of the section $22 \mathrm{I}(\mathrm{d})(3)$ below-market interest rate program for moderate income families and individuals by the Federal National Mortgage Association so as to permit the financing of 140,000 units per year. Ultimately, it should include the establishment of broader programs which would stimulate greater participation by the private housing industry in this market.

5. A national objective should be to establish vacant land development programs and land reserve programs to provide the new housing and related facilities needed to accommodate population growth in urban centers, to permit the renewal and redevelopment of slums and blighted areas, and to support the model cities program. 
6. In order to expand the rehabilitation of existing housing to significant levels, there should be recognition that large-scale rehabilitation programs will require capital and other subsidies comparable to those involved in acquiring and clearing slum properties. Because most properties suitable for rehabilitation are occupied by families and individuals of low and moderate income, there should likewise be recognition that write-offs of part of the costs of rehabilitation will be generally required in order to produce monthly charges within the financial capacity of that market. 